Issue 1/2018

\title{
FUTURE MODERN RETAIL SOLUTIONS AND SHOPPER EXPERIENCE
}

\author{
Viorica JELEV ${ }^{1}$ \\ ${ }^{1}$ Spiru Haret University, Economic Sciences Faculty, Romania, Fabricii Street, \\ nr. 46G, Sector 6, Bucharest, Postcode: 030045, Telephone / Fax: \\ (004021)3169783, Email: jelevviorica@yahoo.com
}

\begin{abstract}
Artificial intelligence and automation will radically change the world, but if we want society to benefit from these changes, we need to properly prepare ourselves through an education tailored to new times. Until the last century, it was the manufacturing industry that created jobs. But today, as a result of the existence of artificial intelligence, robots, the manufacturing industry is no longer the main driver of job creation, but the service industry.

As competition grows, brand manager imagination needs to work, and sales growth solutions need to focus on customer focus attention. It is a difficult task if all brands offer discounts in the malls they are in, and the announcement of differentiation is put to the attention of specialists who offer solutions for fun of any kind for the clients. The article aims to present the evolution of world trade in recent years and the various ways of diversion invented by retailers to keep customers in store chains longer time for them to buy more.

The conclusion of this article will focus on the idea of future trade based on modern technology inside stores, which will lead to profound changes in customer buying behaviour.
\end{abstract}

Keywords: e-commerce; omni shopper; "clickdependshopper”; intelligent selling; omni channel.

JEL Classification: $\mathrm{F}_{10}, \mathrm{M}_{30}$

\section{Introduction}

The current article speaks about the evolution of international trade in the recent years, but also about new ways to sell products in stores according to buyers typology, most of which appeal to shoppers' entertainment through numerous online and offline methods.

Finding innovative methods of retaining people as much time as possible in the visitor's sales area, in order to be converted into buyers, leads to increased sales and business profits. 


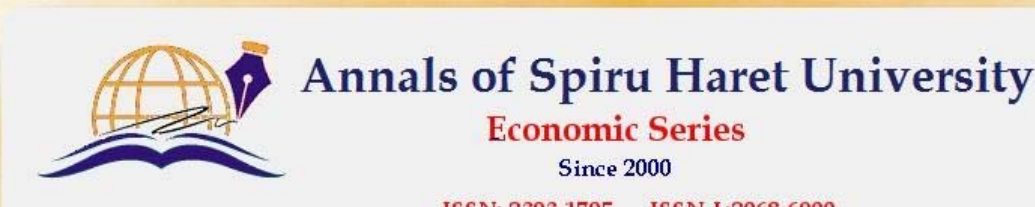

ISSN: 2393-1795 ISSN-L:2068-6900

Issue 1/2018

The article contains three parts in which we have shown the evolution of world trade in the recent years, according to Eurostat data, a GfK study and an Euler Hermes study. The results of the study refer to the orientation of the Romanian shoppers in the store, as well as the beginning of the end of the retail market as we know it today in Romania and in the world, thanks to the technological inventions that are meant to keep buyers for a longer time in the physical stores in order to increase sales.

These retail inventions will educate buyers in new technologies and give them new shopping experiences. The future in retail is very close and buyers will become addicted to the touchscreen of smartphones. We can even call them "clickdependshoppers" (word invented by me).

With the development of technology and the improvement of product delivery methods, younger generations have gradually given up their visit to the store and chose to fill their basket with one click. Practically, online stores have shown that they have not only more "storage space" than traditional ones, but also product delivery facilities. Here are true reasons for traders to find ways to keep consumers in classic stores.

Because artificial intelligence and entertainment has long been a marketing method for increasing sales in large chain stores, the subject has not been much debated in the literature. Innovative methods for brand managers from around the world to keep shoppers as long as possible in stores will be described in future specialist sales books.

\section{Literature review}

In order to develop this topic, I have used the information I have received at the specialized conferences I have attended in recent years, such as the Retail Arena, an annual conference dedicated to the large retail chains, online stores and service providers, logistics specialists and marketing, business owners and manufacturers in the FMCG industry, as well as the Biz conferences, destined for marketing, entrepreneurship, social media. I used information from the specialized courses I wrote for Merchandising and International Marketing, as well as the book of Gh. Pistol, Internal Trade - Course Notes. We also used statistical information and data made available to researchers by the European Statistics Office, Eurostat, on the evolution of international trade. Also two studies by GfK for 2017 and Euler Hermes Romania. 

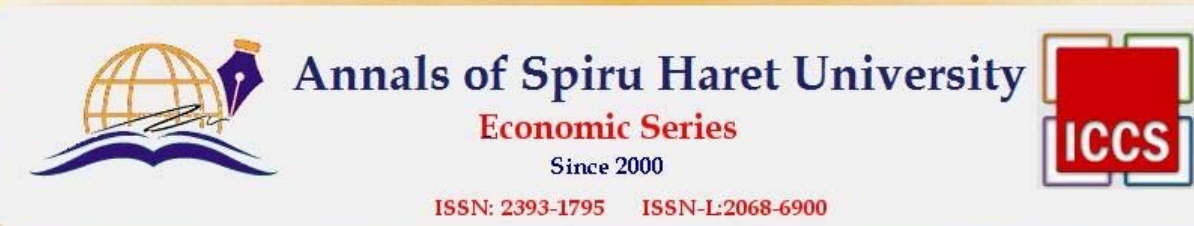

ISSN: 2393-1795 ISSN-I-2068-6900

Issue 1/2018

\section{World trade - statistic data}

From school I learned what trade means. According to the definition, it means supplying goods in exchange for means of payment, usually money, or other commodities, the price of which is determined by the market relationship between "demand" and "offer". As we know, trade is limited to buying, transporting and selling goods.

Commerce needs to always adapt to new sales techniques to meet new and ongoing customer requirements. Once the consumer is exposed daily to numerous offerings that invade his space and mind, by all means sensed by the senses, he becomes increasingly demanding. The sight, the hearing, the smell, the touch and the taste are continually tested.

Table no. 1. International trade, 2014-2015

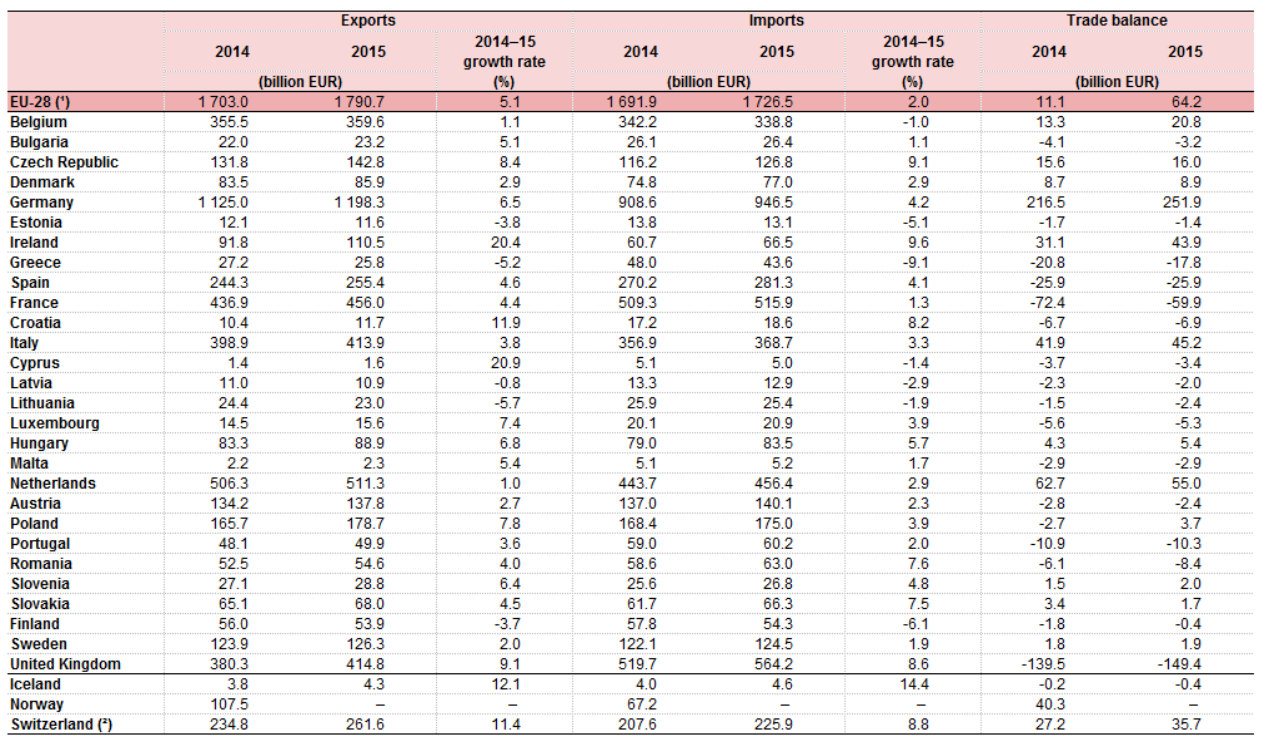

()) External trade flows with extra EU-28.

(2) Including Liechtenstein.

Source: http://ec.europa.eu/eurostat/statisticsexplained/index.php/International trade_in_goods/ro 


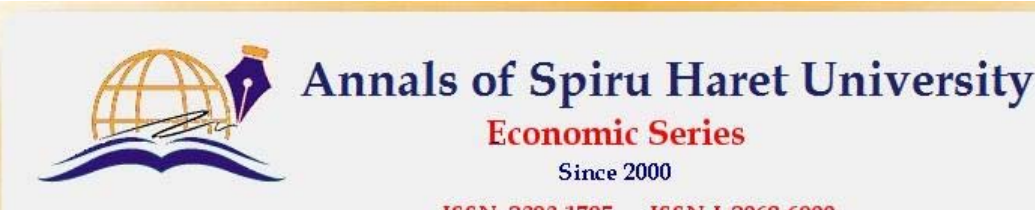

ISSN: 2393-1795 ISSN-L:2068-6900

\section{Issue 1/2018}

In this new world of aggressive commercials, shopping becomes more and more pretentious by the education it acquires not only in school, but also by means of online and offline media.

Under these circumstances, brand managers need to find new and new ways to increase sales at sales points, by conducting numerous studies to find new types of shops and their inclinations towards consumption.

According to the International Commodity Trade study, developed by the EU Statistical Office, Eurostat, the European trade of the 28 Member States carries about $15 \%$ of world commodity trade. The value of international trade in goods is significantly higher than that of services (approximately three times), reflecting the nature of certain services that are an obstacle to cross-border trade. China and the United States were the two largest players in international trade since 2004, when China surpassed Japan.

The EU-28 international commodity trade with the rest of the world (sum of exports and extra-EU imports) was estimated at EUR 3517 billion in 2015 (Table no. 1 and Figure no. 1). Both imports and exports increased compared to 2014, but this increase was higher for exports ( $€ 88$ billion) than for imports ( $€ 35$ billion). Therefore, the EU-28 trade surplus has increased from $€ 11$ billion in 2014 to $€ 64$ billion in 2015.

Following a dramatic decline in both exports and imports in 2009, the EU-28 has increased its exports to $58.7 \%$ over the next four years to reach a record high of 1,737 billion in 2013. Exports then declined to 1.9\% in 2014 before rising to $5.1 \%$ to reach a new peak in 2015 of EUR 1,791 billion. Instead, the increase in imports after 2009 was $45.5 \%$ over three years, to reach a peak in 2012 of EUR 1,798 billion. Although imports declined to $6.2 \%$ in 2013 before stabilizing (to $0.3 \%$ ) in 2014 and increasing by $2.0 \%$ in 2015 , it is still below the 2012 level. Germany was, by far, the largest Member State in terms of trade outside the EU-28 in 2015, contributing $28.2 \%$ of EU-28 exports of goods to third countries and making almost a fifth (18.8\%) of EU-28 imports. The following three largest exporters, the United Kingdom (12.9\%), France (10.5\%) and Italy (10.4\%) remained the same as in 2014 (although France's exports outside the EU have exceeded those of Italy), these being the only EU Member States with a two-digit share of EU-28 exports. The United Kingdom (15.2\%), the Netherlands (14.4\%), France (9.5\%) and Italy $(8.9 \%)$ were immediately behind Germany as regards the volume of imports of goods from third countries in 2015.

The relatively high percentage for the Netherlands can, at least in part, be explained by the considerable volume of goods entering the EU via Rotterdam, 218 


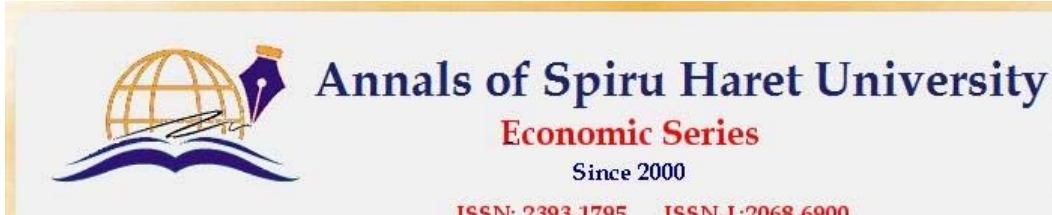

ISSN: 2393-1795 ISSN-I*2068-6900

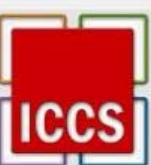

Issue 1/2018

which is the EU's largest maritime port. The largest surplus of extra-EU-28 commodity trade, estimated at EUR 179.4 billion in 2015, was recorded by Germany, followed by Italy (EUR 33.7 billion) and Ireland (EUR 29.3 billion).

Between 2010 and 2015, the value of EU-28 imports and exports increased for all the product groups shown in Figure no. 1, excluding imports of mineral fuels and lubricants, which decreased to $14.7 \%$. The highest rate of growth in imports [5] was reported for food, beverages and tobacco, with an increase of $49.5 \%$. Imports of these products also increased significantly (up to $33.8 \%$ ), but this increase was overtaken by chemicals and related products, where there was an increase of $34.8 \%$.

\section{The Romanians have spent more and have focused on more expensive products in 2017}

Year 2016 was another good year for the consumer goods industry, both for retailers and producers, according to a study by GfK. 2017 was the second consecutive year when Romanians had an increased appetite for more expensive products and for higher expenses. The FMCG (Fast Moving Consumer Goods) market grew by $3.4 \%$ compared to 2016 . Behind this growth is a $3 \%$ increase in purchases and up-trading (consumer orientation towards products superior in terms of price). Unlike in 2016, up-trading was found in both modern and traditional trade. This phenomenon has led to an increase of one percentage point of premium brands at national level, to the detriment of other price categories.

Romanians buy less commonly used goods, but spend more on a purchase act. Reducing the frequency with which people go shopping was noted exclusively in the fresh food categories, while for home care products the purchasing frequency increased.

As shown in Figure no. 1, two-thirds of spending goes to food.

In current consumer goods, food categories still dominate Romanian spending and account for $66 \%$.

Household care products, beverages and personal care products had the greatest growth. However, considering the size of the category segments, fresh food and beverages were the ones that contributed most to the growth of the FMCG market. Among the categories that registered increases in 2016 are seafood and fish, frozen foods, exotic fruits (avocado, pomegranate, etc.), cider, champagne, etc.

Retail businesses grew in Romania five times more than European average in 2017. 

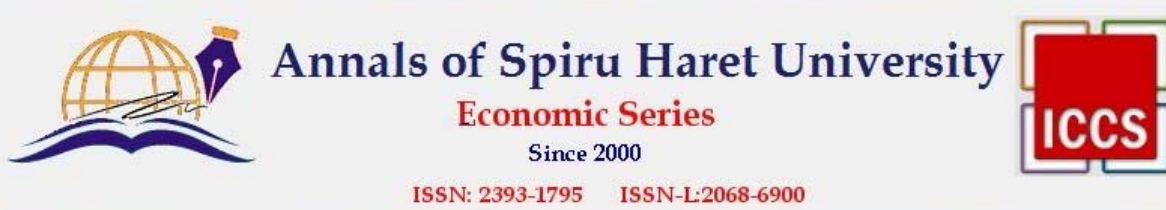

Issue 1/2018

Figure no. 1. Market share January-September 2017 Retail and FMCG Romania

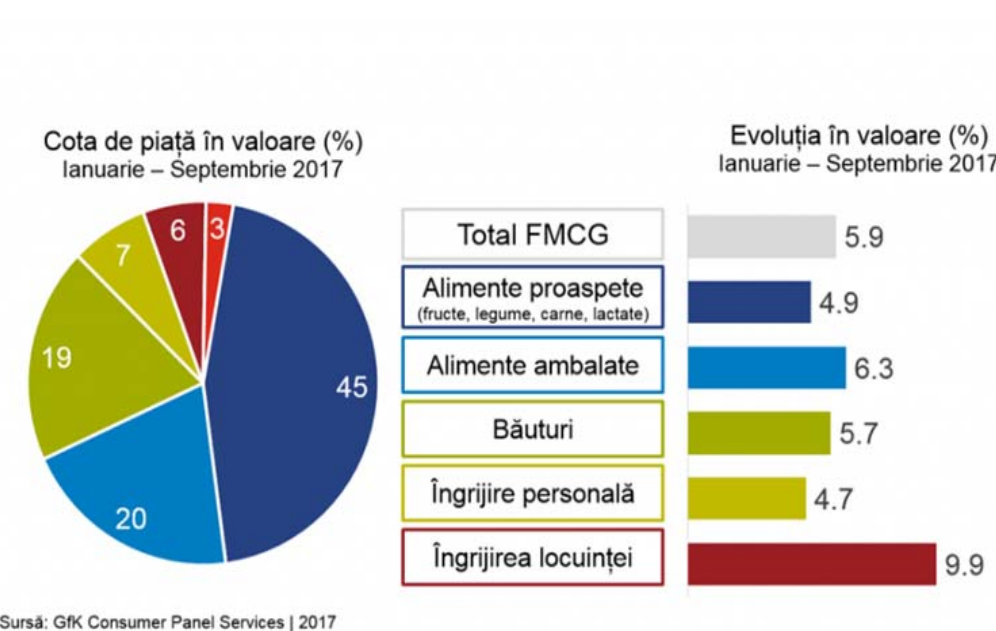

Source: GfK Consumer Services Romania, 2017

The turnover growth rate of the retail units in Romania was of $10 \%$ this year, far above the average of $1.5 \%$ in the EU countries and five times more the EU-27 average (excluding the UK), according to a report by GfK market research company. On the other hand, even if it is growing, the purchasing power in Romania is among the lowest in Europe.

The local retail market has now reached at around 40 billion Euros, according to another study by Euler Hermes, a company active in providing commercial credit insurance solutions, part of the Allianz Group.

Last year, the retail sector increased by $12 \%$, according to Euler Hermes, which does not provide a figure for this year's development. The growth of the Romanian retail sector came amid the increase in the gross minimum wage (currently 1,450 lei), the VAT reduction from $24 \%$ to $19 \%$ and the increase of the employment rate by $0,16 \%$ in 2016 compared to 2015 .

Last year (2017), some 230,000 square meters of new commercial space entered the market, $40 \%$ up from 2015, while 240 new food stores were opened, among the most active players in this area being Profi (134 new stores), Mega Image (60), Lidl (11) and Kaufland (6). In Romania, 85\% of products sold in modern trade chains are of mixed origin, and $15 \%$ are local products. 


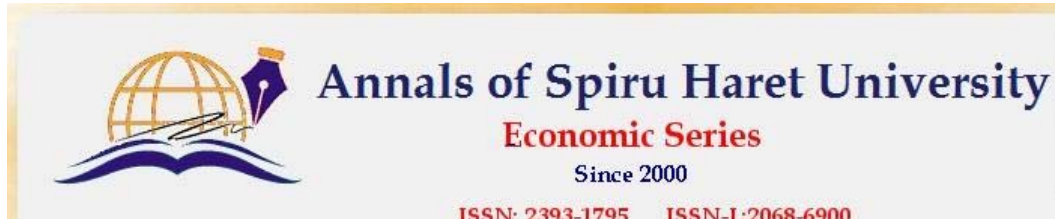

ISSN: 2393-1795 ISSN-I-2068-6900

Issue 1/2018

Romania is, after Turkey, Russia, France and Italy, in the top of commercially increasing countries: from 50 to 100 square meters per thousand inhabitants in the last 4 years, but well below the European average. In major cities, there is an increase in appetite for large spaces, while street areas remain with a high rental price. The retailers (Profi, Penny, Lidl) continue to develop networks in smaller cities where rental rates are lower. For 2018, estimates show that more than 43,000 square feet of commercial space will open in Romania.

The challenge of 2017 was the growth of the market in small and medium cities, according to Euler Hermes. Statistics show that retail in large chain stores has a weight of $62.4 \%$ in Romania (February 2017) compared to $90 \%$ in developed countries. In this context, the retail sector has a chances of growth with a concentration in smaller towns (with less than 100,000 inhabitants), where trade is for the time being the street shops. In addition, traders such as Lidl target the less developed regions (Moldova). On the logistics side, retailers have begun to look for new expansion areas. eMag is looking for a new logistics centre, and Carrefour and Kaufland will also expand their logistics centres serving stores in Bucharest. Profi opened the first logistics centre in Cluj in 2017.

At the same time, traders also focus on developing online stores and offering alternative payment options. Il Passo said it already achieved $11 \%$ of online business, with Intersport opposed to just $1 \%$, while Noriel, the largest toy distributor, said that over $60 \%$ of the orders are placed on mobile phone and only $10 \%$ are paid by electronic commerce. Bookstores aim for a $70 \%$ increase in online sales. Nevertheless, there is room for growth in the food sector: Carrefour, Metro and Selgros already have online platforms, offering them to customers through the Bringo delivery platform. International traders accelerated this development in 2017 with Mega Image, Kaufland and Cora entering the online market in 2017.

Euler Hermes Romania estimates that the evolution of the retail sector will continue to be positive in 2018, influenced by positive macroeconomic indicators and recent fiscal changes. However, the increase in the current account deficit and the reappearance of inflationary pressures could alleviate trade's potential growth.

The study still presents positive data for Romania when considering the economic situation in Europe. In Figure no. 2, it is seen that Romania is framed in the minimum risk area for the Country Risk Ratio Indicator for 2017 when analyzing Gross Domestic Product - GDP - growth for 2016 and 2017.

Economic growth in Central, Eastern and Southeast Europe is set to rise and expand by $+2.5 \%$ in 2017 , after $+1.7 \%$ in 2016 . Reasons include:

- Accelerating in the Eurozone; 


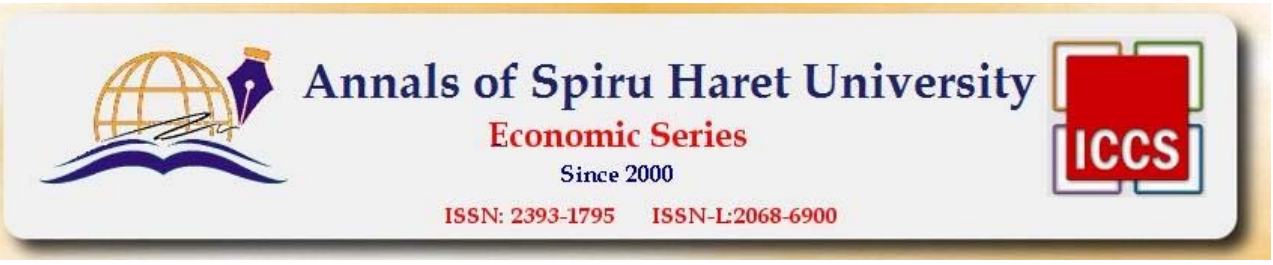

Issue 1/2018

- Turkey's rebound to $+3.7 \%$ growth in 2017 ;

- Russia's exit from recession: $+1.3 \%$ growth is forecast in 2017 .

Modern commerce in classic shops must be a priority in this period, when online sales grow spectacularly in Romania and the world.

Figure no. 2. Emerging Europe: The European Dividend

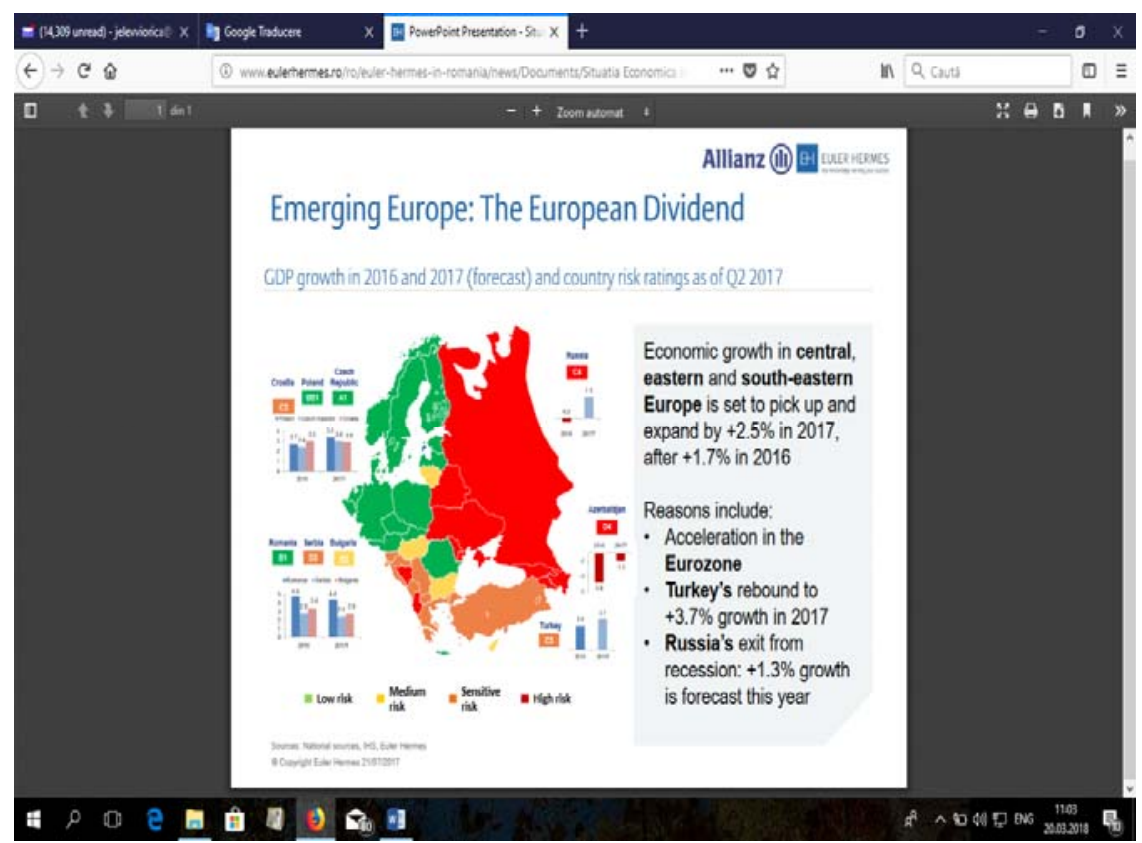

Source: http://www.eulerhermes.ro/ro/euler-hermes-in-romania/news/Pages/ Situatia-Economica-in-Europa.aspx

It seems that the hypermarket remains consumers' favourite retail in the future. Modern trade covers $57 \%$ of the total FMCG market in Romania. During 2016, modern retailers earned 2 percentage points versus 2015. Supermarket and discount formats contributed most to the growth of modern commerce, gaining a half a percentage point each. The growth of these formats comes from attracting more buyers in stores and increasing the purchasing frequency. Although they had a steady market share in 2016, hypermarkets remain the most important modern channel, accounting for more than a quarter of total home FMCG sales. 


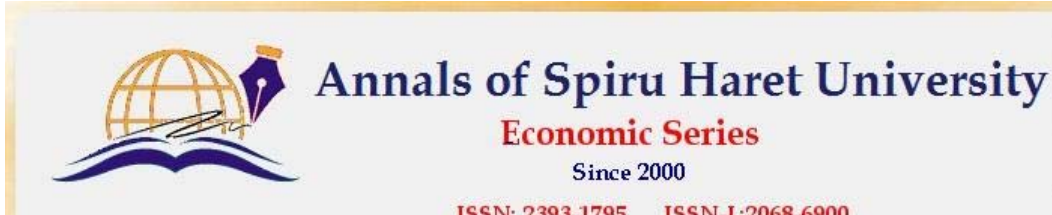

ISSN: 2393-1795 ISSN-I-2068-6900

Issue 1/2018

Compared to other years, in 2016 retailers' concentration has diminished their growth rate. The market share of the top 10 retailers increased by only 1 percentage point (compared with 3 points in 2015). Among the most active retailers in terms of market share growth are Lidl and Profi. Traditional trade has had a negative evolution during 2016, the decrease of 2 percentage points being determined by a reduction in the frequency with which Romanians buy from traditional formats.

Analysts characterize 2018 as follows: Unlike previous years, 2018 will be characterized by inflation as a result of fiscal relaxation and VAT cuts in 2015, 2016 and 2017 which anticipates a slower growth rate.

\section{Technology innovations and customer experience in retail}

The economic crisis has inevitably reconfigured the conditions on the retail market, its consumption rhythm and its prudent purchasing behaviour has moderated. These are just some of the predictable trends in the current evolution of consumers where industry players need to quickly identify the most effective solutions. Marketing, retail and FMCG specialists are discussing the challenges, difficulties and trends of the retail industry in the current economic context, meeting in conferences dedicated to the field and trying to provide effective solutions and practical advice for attracting consumers to shopping areas and consolidating market position, based on the latest in-store innovations, helping players with the most effective strategies and techniques for brand differentiation and consumer loyalty. By interacting directly with representatives of renowned companies in developing customer loyalty strategies, practitioners who provide specialized analysis, concrete business cases and practical exercises demonstrate how positive customer brand experience can become a strategic tool for optimizing profits and earnings.

The world of trade is turning every day and shoppers are part of the change. Today, we know that the heart of change is the client of the millennium - the one that animates the whole story of modern retail. The store of the future could have showcases that interact with passers-by inviting them into the retailer's universe. It could have shelves in the form of touchscreens to allow customers to turn all the brand's products, not just the ones available in the physical form in the store, or they could move into the street in the form of simple billboards that the phones scan for shopping. The Future Store could use smartphone to find out customers' preferences or send them to the test room for all the products they want. Retailers could use intelligent mirrors to show consumers how they would look with a certain shade of lipstick without touching their lips, or as it would look in a 


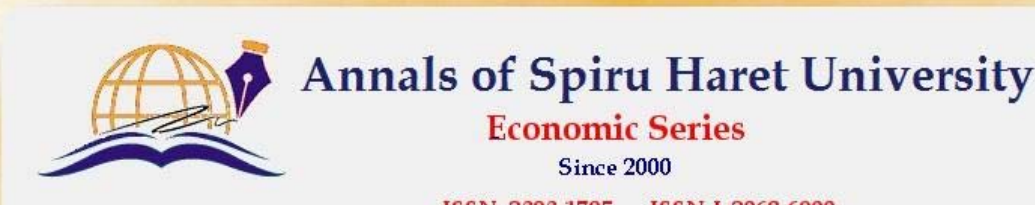

ISSN: 2393-1795 ISSN-L:2068-6900

Issue 1/2018

particular dress adapted to the physical forms of the client. In addition, they could offer their customers not only a shopping experience, but also a lifetime experience to get them out of their daily routine.

All these are changes that our consumer behaviour are triggering, which a number of brands have implemented and which we will continue to write about to outline an overview of the future of retail.

\section{Intelligent showcases that create a brand experience}

The brand first comes into contact with the passers-by through a shop window. But what if technology could intervene to stop passers-by through an interactive experience and manage to pass on the brand's characteristics? LEGO has done this in Chicago through a Kinect device installed in front of the showcase, allowing the tracers to turn into LEGO men to control their movements with their body.

Other brands that resorted to intelligent showcases were Bloomingdales, which allowed passers-by to sample glasses, or BMW, in the store where the showcases turned normal cars on the street into cars of the future.

\section{Virtual racks that ease the buyer's decision and effort}

Innovation also comes in terms of store shelves that can support the retailer's business more than we have become accustomed to. Adidas used Intel technology for adiVERSE Footwear Wall, a digital wall with touchscreens that allowed shoppers to view 3D not just stock products but up to 8,000 branded products.

Adidas allowed those who entered the store to obtain information that they would normally find on the internet rather than in a physical store. Together with classical promotions in the store, the initiative has created a true brand experience in the store and a 500\% increase in sales after installing the interactive wall.

\section{Intelligent mirrors that ease our choice}

Technology also has positive implications for hygiene. Marks \& Spencer has installed 10 smart mirrors that help customers find out what they look like with a certain shade of foundation or a certain lipstick without really trying it on their skin.

\section{Digital content inside the products to tell a story}

If every glimpse of a store can be modified with state-of-the-art technologies to meet the needs of consumers, why brands would not enrich consumer experience through products? Burberry chose to tell a story including digital tags in its products that could be scanned with a mobile device or a high-tech mirror to trigger a short film showing how much care each individual object was working on. Burberry also included high-tech mirrors inside the store or the London emblem. Once the people 


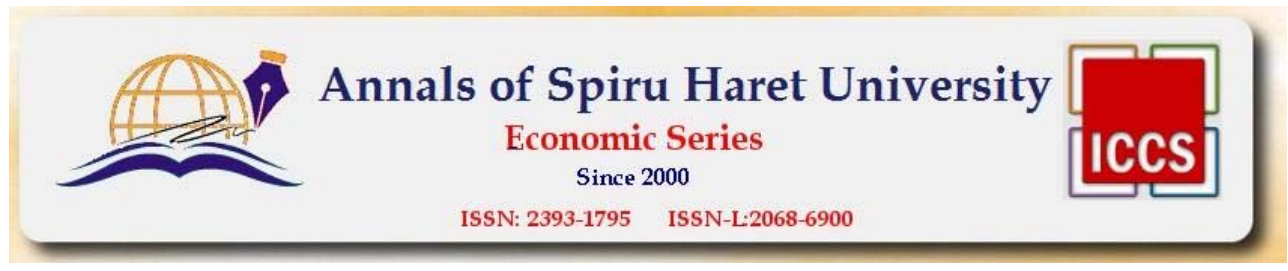

Issue 1/2018

in the store were probing a story, the mirror screens responded in real-time to the digital tags inside, launching the movie about how that coat was created.

The service was part of the Made to Order campaign, where consumers could order with a smartphone produced directly from the presentation podium. The clothes were delivered in 9 weeks, customized after the buyer's measurements and having a plaque engraved with his name (for example: "MADE FOR VIORICA JELEV").

\section{Customize this in-store}

Neiman Marcus, a chain of premium clothing stores, has launched a locationaware application for iOS called NM Service. As soon as a user enters the store, the sales consultants are announced through the application, also receiving the entire store history of the customer, along with their profile image on Facebook, so that they can provide the right recommendations. The application allowed the user to even select the desired sales consultant and schedule it. It can happen to anyone who goes shopping alone and wakes up in the situation of not knowing what to choose between several outfits, in which case another opinion is needed. For such situations, Voto has been created an iOS application that enables users to distribute in their network pictures of clothing items that they like, followed by friends enrolled in a social media profile application to vote. Voto can also be used by brands to allow them to share pictures of their products in their network and to obey the fans' votes, thus giving information about their preferences and trends.

Hointer, who sells men's designer jeans, has launched a new store format together with an app that will ease the buyer's experience. In a large store, with no employees interacting with customers, each pair of jeans is exposed along with a $\mathrm{QR}$ code. With an application, the user can scan it, choose the right size, and the desired products will wait for the sample cab, all robotic. From the application, while in the test booth, the costumer can ask for another pair of jeans.

These are just a few examples of brands that have integrated modern trends in a future store in response to the changes in buyer's behaviour.

\section{Mobile payment service}

Auchan Retail launches in Italy AuchanSpeedy, a mobile payment service, developed with Mastercard, which offers the customer the possibility to avoid the classic process of scanning and paying products at the cash registers.

With these applications, buyers will become addicted to the click of phones and we will be able to call them "clickdependshoppers".

So omni-channel retailing is focused on creating a seamless consumer experience for the connected customer who uses traditional and digital shopping channels simultaneously throughout the purchase journey (Figure no. 3). 


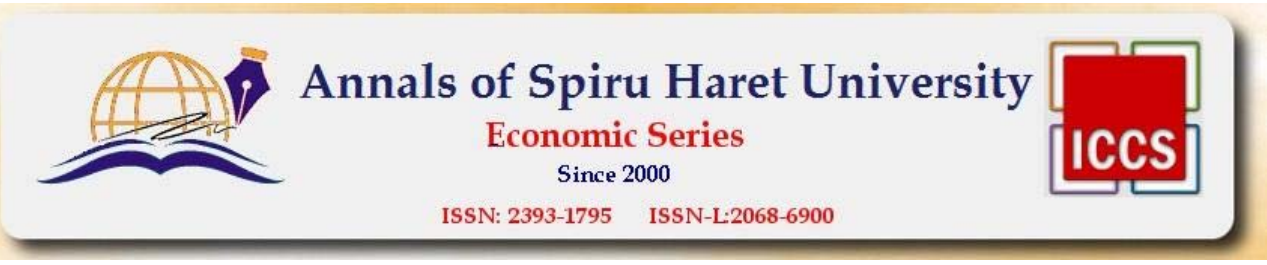

Issue 1/2018

Figure no. 3 Omni-channel retailing

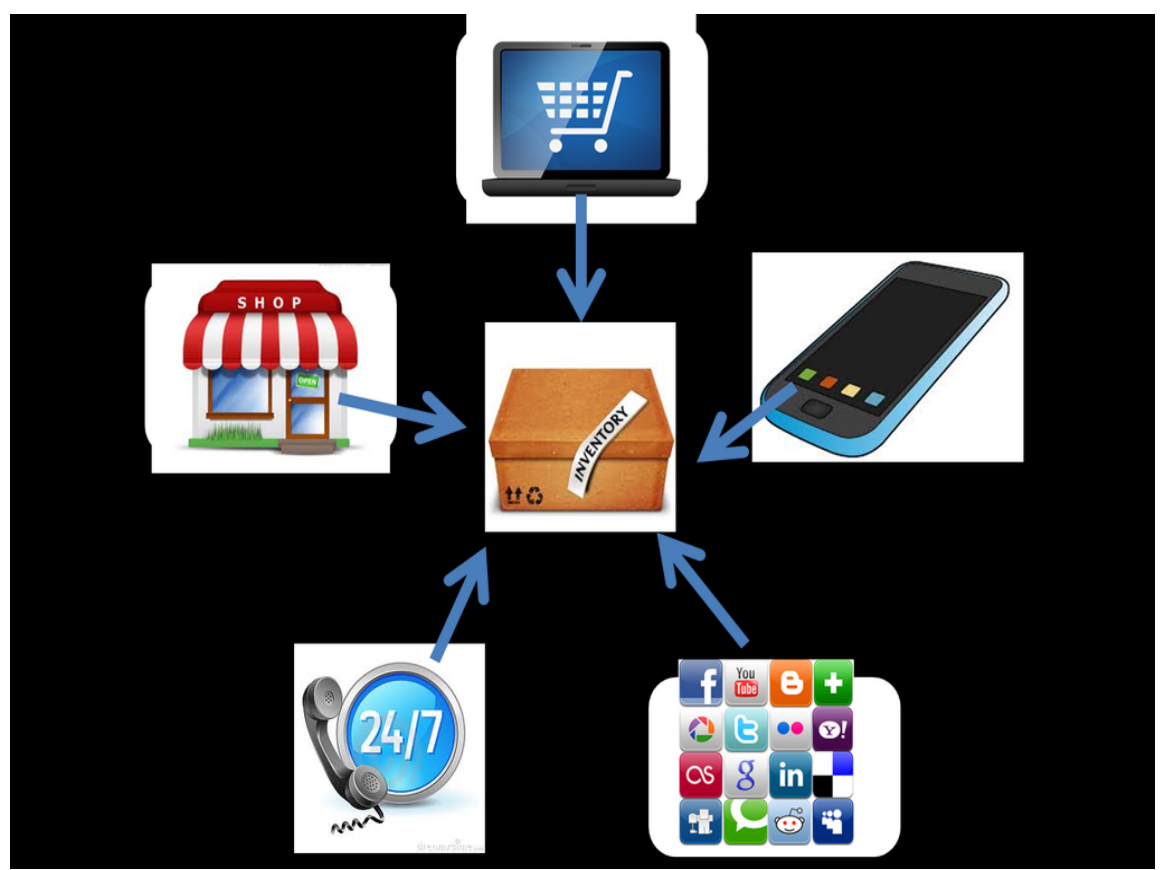

Source: http://comertelectronic.eu/e-commerce-inglobat-in-noul-concept-omni-channel/

\section{Conclusions}

Will the future only depend on a touch on a touchscreen? It is the question that more and more people ask in choosing convenience in exchange for physical effort. In a technology world, more and more time-consuming and time-dependent, online shopping tends to take the place of traditional shopping.

With the development of technology and the improvement of product delivery methods, younger generations have gradually given up their visit to the store and chose to fill their basket with one click. Practically, online stores have shown that they have not only more "storage space" than traditional ones, but also product delivery facilities.

Modern trade arrived also in Romania (in the hypermarkets, supermarkets, convenience stores and discount) to a market estimated at over 18 billion Euros.

Alongside, the large retail stores that have opened in the last 15 years in Romania have developed networks and online sales. Originally viewed as simple 


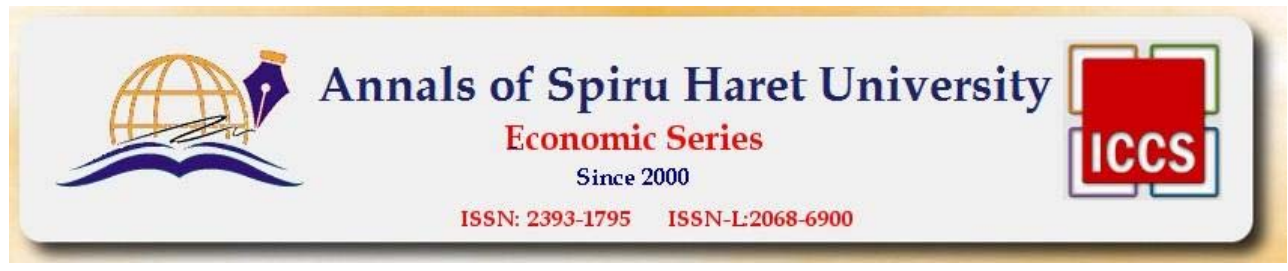

Issue 1/2018

online platforms, they have come to show, from the point of view of products' offering, as shops in their entirety. According to players in the sector, online sales market in Romania is now somewhere around one billion Euros, with clear upward trend in the coming years.

In offline or online retail if retailers have the same prices, the same commodity and are relative to the same consumer distance, they have to find ways to encourage customers to choose their store. Brands and smart retailers are already adapting their integrated marketing plans to ensure that all forms of m-commerce and e-commerce, online and offline, are a strong point in the acquisition process, and those who do not do it risk losing a significant market share and failing to attract a new generation of buyers. The store remains the centre of gravity for the omni-shopper. A destination for the value of entertainment and social interaction, and, although value is important, promotions are essential for less than $20 \%$ of the omni-shoppers.

Expert advice refers to adapting experience based on product, retailer, and space available.

Everything depends on all who work in retail or with retailers. As long as the sales representatives are ready for change and are looking to do more and better with the same resources, as well as they are taking the effort to give the end consumer all the reasons to prefer them, then the future will look a lot like what the shoppers want.

It is the time for the companies involved in retail to proactively engage and support the training of future employees in the field, and envisage a pleasant and profitable future.

\section{References}

1. Cătoiu, Iacob, Gârdan, Daniel Adrian, Gârdan, Doru Lucian, "Mobile marketing future trends," Annals of Spiru Haret University. Economic Series, Vol. 10, No. 1, 2010.

2. Cojocaru, Oleg, http://incomemagazine.ro/articles/painea-si-circul-din-malluri-aduc-cupana-la-70-mai-multi-clienti, 24 iunie, 2010

3. http://comertelectronic.eu/e-commerce-inglobat-in-noul-concept-omni-channel/

4. http://minio.ro/posts/portfolio-item/omnishopper-faceti-cunostinta-cu-consumatorulviitorului/

5. http://www.eulerhermes.com/group/who-we-are/Pages/default.aspx

6. https:/www.retail-fmcg.ro/retail/auchan-retail-lanseaza-auchanspeedy.html?ct=t (EMAIL_CAMPAIGN_12_13_2017)\&mc_cid=a833a9d423\&mc_eid=ca7ca4c3e3

7. International trade in goods in http://ec.europa.eu/eurostat/statisticsexplained/ 


\section{Issue 1/2018}

index.php/International_trade_in_goods/ro

8. Ionescu, Adrian N., GfK: Retail businesses will grow in Romania five times more than European average in 2017, http://cursdeguvernare.ro/gfk-retail-businesses-willgrow-in-romania-five-times-more-than-european-average-in-2017.html

9. Jelev Viorica, Merchandising, Note de curs (Blackboard, 2017).

10. Jelev, Viorica, "European trade where? Retail entertainment," JEDEP, vol. 6, nr. 4, 2017.

11. Jelev, Viorica, Marketing internațional (București: Editura Fundației România de Mâine, 2007).

12. Loyalty marketing in a Trumpian world in https://www.retailcustomerexperience.com/ companies/media/achieveglobal/

13. Neferu, Andreea, https://www.newmoney.ro/toti-banii-din-buzunar-piata-de-retail-ajunsla-40-de-miliarde-de-euro/

14. Pistol, Gh., Pistol, Luminița, Albu, Gh., Manea, Gelu, Comerțul interior. Teorie și practică (București: Editura Economica, 2004).

15. Shopper culture in http://www.shopperculture.com/the-complex-shopper/

16. Studiu GFK - produse in http://www.retail-fmcg.ro/servicii/studii-de-piata-servicii/studiugfk-produse.html 


\section{DOCTORAL AND POSTDOCTORAL}

PAPERS 
